University of Nebraska - Lincoln

DigitalCommons@University of Nebraska - Lincoln

Papers in the Earth and Atmospheric Sciences Earth and Atmospheric Sciences, Department

March 2000

\title{
Hydrologic Variation in the Northern Great Plains During the Last Two Millennia
}

Sherilyn C. Fritz

University of Nebraska-Lincoln, sfritz2@unl.edu

Emi Ito

University of Minnesota

Zicheng Yu

University of Minnesota

Kathleen R. Laird

Queens University, Kingston, Ontario

Daniel R. Engstrom

St. Croix Watershed Research Station, Science Museum of Minnesota, dre@smm.org

Follow this and additional works at: https://digitalcommons.unl.edu/geosciencefacpub

Part of the Earth Sciences Commons

Fritz, Sherilyn C.; Ito, Emi; Yu, Zicheng; Laird, Kathleen R.; and Engstrom, Daniel R., "Hydrologic Variation in the Northern Great Plains During the Last Two Millennia" (2000). Papers in the Earth and Atmospheric Sciences. 41.

https://digitalcommons.unl.edu/geosciencefacpub/41

This Article is brought to you for free and open access by the Earth and Atmospheric Sciences, Department of at DigitalCommons@University of Nebraska - Lincoln. It has been accepted for inclusion in Papers in the Earth and Atmospheric Sciences by an authorized administrator of DigitalCommons@University of Nebraska - Lincoln. 
Published in Quaternary Research 53:2 (March 2000), pp. 175-184; doi:10.1006/qres.1999.2115

Copyright (c) 2000 University of Washington; published by Academic Press/Elsevier. Used by permission. http://www.sciencedirect.com/science/journal/00335894

Submitted May 12, 1999.

\title{
Hydrologic Variation in the Northern Great Plains During the Last Two Millennia
}

\author{
Sherilyn C. Fritz ${ }^{\text {a }}$, Emi Ito ${ }^{\text {b }}$, Zicheng Yu ${ }^{\text {b,* }}$, Kathleen R. Laird ${ }^{\mathrm{c}}$, \\ and Daniel R. Engstrom ${ }^{d}$ \\ a Department of Geosciences, University of Nebraska-Lincoln, Lincoln, Nebraska, 68588 \\ ${ }^{\mathrm{b}}$ Department of Geology \& Geophysics and Limnological Research Center, \\ University of Minnesota, Minneapolis, Minnesota, 55455 \\ c Department of Biology, Queens University, Kingston, Ontario, K7L 3N6, Canada \\ d St. Croix Watershed Research Station, Science Museum of Minnesota, \\ Marine-on-St. Croix, Minnesota, 55047 \\ * Present address: Canadian Forest Service, 5320 122nd St., \\ Edmonton, Alberta T6H 3S5, Canada.
}

\begin{abstract}
Reconstructions of lake-water salinity at decadal resolution for the last 2,000 years are compared among three lakes in North Dakota to infer regional patterns of drought. The intersite comparisons are used to distinguish local variation in climate or hydrology from regional patterns of change. At one lake, diatom-inferred salinity and lake-water $\mathrm{Mg} / \mathrm{Ca}$ inferred from ostracode shell chemistry are coherent, both in terms of direction and magnitude of change, indicating that each is a robust technique for reconstructing lake-water chemistry. The data show that the last 2,000 years have been characterized by frequent shifts between high and low salinity, suggesting shifts between dry and moist periods. Long intervals of high salinity suggest periods of multiple decades when droughts were intense and frequent, thus indicating times when drought was more persistent than in the 20th century. Both the Medieval Period and Little Ice Age were hydrologically complex, and there is no clear evidence to suggest that either interval was coherent or unusual in effective moisture relative to long-term patterns. Differences among the three sites may be attributed to variation in local hydrology, and these differences emphasize the need for multiple sites in deriving regional climate interpretations from paleoecological data.
\end{abstract}

Keywords: paleoclimate, paleolimnology, paleohydrology, drought, northern Great Plains, saline lakes, diatoms, ostracodes

\section{Introduction}

High-resolution studies of the climate of the last 2,000 years can be used to examine temporal and spatial patterns of natural climate variation under large-scale boundary conditions that are roughly similar to those of today. Thus, these data can provide a baseline of climate variation before major anthropogenic modification of the climate system. Recent syntheses of high-resolution paleoecological and historic data suggest that 20th-century global and regional temperature trends may be unusual relative to those of the past four to six centuries (Mann et al., 1998; Overpeck et al., 1997). More-limited data are available regarding precipitation variation, although paleoecological reconstructions suggest that, at least in some regions, the 20th century does not encompass the full range of natural climate variation (Stine, 1994). In the northern Great Plains of North America, diatom-inferred salinity fluctuations, which are a proxy for changes in precipitation minus evaporation $(P-E)$, suggest multidecadal intervals of frequent drought between A.D. 400 and 1200, in many cases greater in magnitude than the Dust Bowl droughts of the 1930s (Laird et al., 1996b). Tree-ring records from the northern Great Plains, which extend back several hundred years, also suggest that the full range of climate variation is not represented in instrumental climate records (Meko, 1992).

Drought can have multiple causes. Moisture patterns at an individual site may reflect convective precipitation operating on a relatively small scale, as well as frontal storms driven by atmospheric circulation systems that affect the distribution 


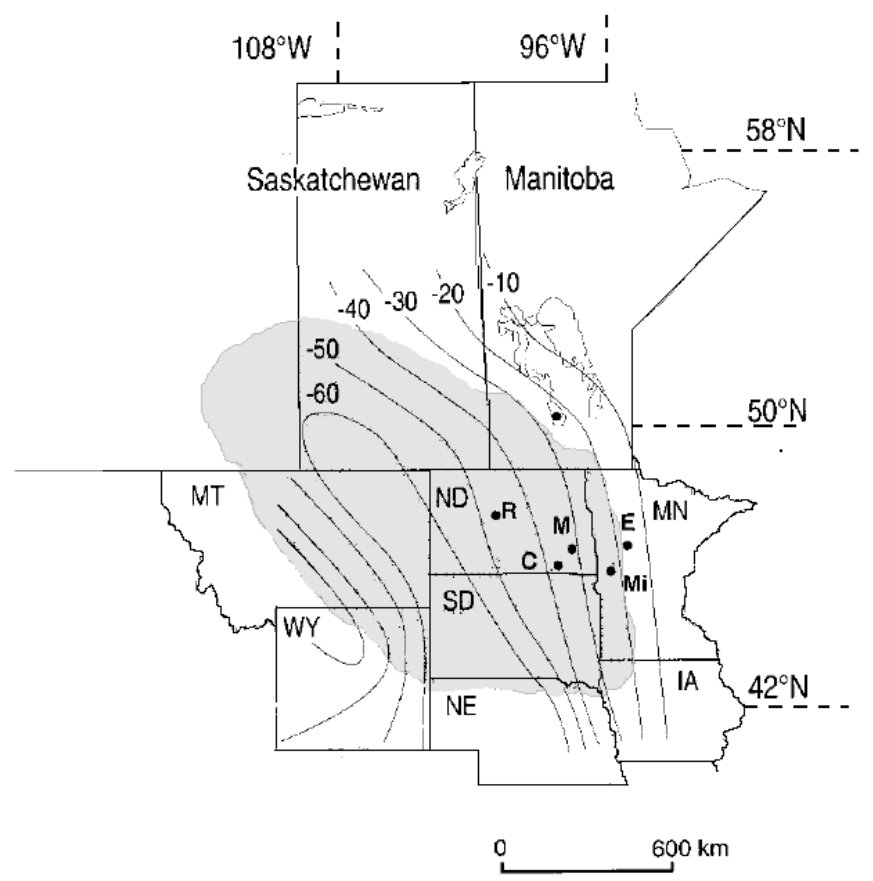

Figure 1. Map of the northern Great Plains (shaded area) showing the location of Moon (M), Coldwater (C), Rice (R), Elk (E), and Mina (Mi) lakes. Isolines are of precipitation minus evaporation (in $\mathrm{cm}$ ). Figure modified from Winter and Woo (1990).

of precipitation over large geographic areas (Hirschboeck, 1991). As a result, climatic inferences from paleoecological data need to be corroborated at multiple sites to distinguish local versus regional variation. The inference of $P-E$ from lacustrine proxy records of salinity assumes that the lake is hydrologically closed and that precipitation and evaporation dominate the hydrologic budget, relative to groundwater and surface flow. Although evaporative forcing is strong in semiarid and arid regions, groundwater flow can be a large component of a lake's water and salt budget (Crowe, 1993; Donovan, 1994). Thus, the rate and pattern of lake response to shifts in $P-E$ depends on water residence time and the rates of response of various components of the hydrologic budget, some of which may lag changes in $P-E$ (Winter and Woo, 1990). As a result, inferences of climate from lake-water chemistry need to be verified or corroborated in some fashion. One approach is to compare inferred lake-water chemistry with historical climate data for the period of the instrumental record (Laird et al., 1998). This method can be used to identify lakes that are sensitive to shifts in $P-E$. However, the components of a lake's hydrologic budget are not temporally static and may change with time. Thus, one can equate shifts in lake salinity with shifts in effective moisture with a high degree of confidence, only if multiple sites confirm a pattern of behavior for the time period of interest.

Here we compare decadal-scale inferences of lake-water chemistry, based on diatom-inferred salinity and $\mathrm{Mg} / \mathrm{Ca}$ ratios in ostracode calcite, for three sites in North Dakota. We use the intersite comparisons to infer regional patterns of drought and shifts in $P-E$ for the last 2,000 years and to distinguish local versus broad-scale influences on lake-water hydrochemistry.

\section{Study Area}

The three lakes (Moon, Coldwater, and Rice) are located in the glaciated part of the northern Great Plains (Figure 1), a region of level to gently rolling topography, which prior to European settlement was characterized by tall-grass to mixedgrass prairie (Carpenter, 1940). The climate is continental, with cold dry winters and moist hot summers. Moisture is derived primarily from the Gulf of Mexico, and precipitation patterns are a result of the interaction of moist Gulf air with dry air masses originating in the Pacific and cold dry Arctic air (Bryson, 1966). Most precipitation falls during the growing season (April to September), and the overall moisture balance is negative $(P-E<0)$. The lakes described here span an east-to-west gradient in precipitation and a north-to-south gradient in temperature (Winter and Woo, 1990). Average annual precipitation and temperature ranges for the 20th century are given in Table 1.

Each of the three lakes is topographically closed, and all inflow derives from precipitation and groundwater discharge. Although most of the precipitation falls during summer months, most is lost to evapotranspiration; regional aquifiers are recharged primarily from snow melt during the spring thaw (Kelly, 1966).

Moon Lake lies in southeastern North Dakota within the Kensal-Oakes drift, an end moraine associated with a readvance of the Des Moines ice lobe of the Laurentide ice sheet (Kelly and Block, 1967). The lake is situated within the Stoney Slough meltwater channel, which cuts across the Kensal-Oakes

Table 1. Selected Geographic and Limnological Data for the Three Study Lakes

\begin{tabular}{|c|c|c|c|}
\hline & Moon Lake & Coldwater Lake & Rice Lake \\
\hline Latitude & $46^{\circ} 51^{\prime} \mathrm{N}$ & $46^{\circ} 01^{\prime} \mathrm{N}$ & $48^{\circ} 00^{\prime} \mathrm{N}$ \\
\hline Longitude & $98^{\circ} 09^{\prime} \mathrm{W}$ & $99^{\circ} 05^{\prime} \mathrm{W}$ & $101^{\circ} 32^{\prime} \mathrm{W}$ \\
\hline Mean annual temp. $\left({ }^{\circ} \mathrm{C}\right)$ & 4.8 & 5.0 & 4.2 \\
\hline Mean annual precipitation (cm) & 46 & 46 & 41 \\
\hline Surface elevation (m) & 444 & 594 & 620 \\
\hline Surface area (ha) & 35 & 50 & 75 \\
\hline Maximum depth (m) & 12.8 & 6 & 10 \\
\hline $\mathrm{pH}$ & 9.1 & 8.9 & 9.0 \\
\hline Salinity (g L L $\left.{ }^{-1}\right)$ & 5.16 & 3.0 & 1.24 \\
\hline $\mathrm{Ca}^{2+}\left(\mathrm{mg} \mathrm{L}^{-1}\right)$ & 11.1 & 21 & 7.9 \\
\hline $\mathrm{Mg}^{2+}\left(\mathrm{mg} \mathrm{L}^{-1}\right)$ & 273 & 439 & 238 \\
\hline $\mathrm{Na}^{+}\left(\mathrm{mg} \mathrm{L}^{-1}\right)$ & 1,368 & 315 & 161 \\
\hline $\mathrm{K}^{+}\left(\mathrm{mg} \mathrm{L}^{-1}\right)$ & 254 & 132 & 45.1 \\
\hline $\mathrm{SO}_{4}^{2-}\left(\mathrm{mg} \mathrm{L}^{-1}\right)$ & 2,598 & 1,881 & 614 \\
\hline $\mathrm{CO}_{3}^{-}+\mathrm{HCO}_{3}^{-}\left(\mathrm{mg} \mathrm{L}^{-1}\right)$ & 164 & 118 & 139 \\
\hline $\mathrm{Cl}^{-}\left(\mathrm{mg} \mathrm{L}^{-1}\right)$ & 497 & 98 & 31.6 \\
\hline $\mathrm{Mg} / \mathrm{Ca}$ molar ratio & 46 & 36 & 49.7 \\
\hline Total phosphorus (ug L ${ }^{-1}$ ) & 51 & 98 & 31 \\
\hline
\end{tabular}

Note: Water-chemistry values are the mean of four measurements taken in 1991 for Moon and Coldwater lakes and two measurements for Rice Lake. Climate data are the mean of the instrumental record. 
Table 2. Radiocarbon Dates from Moon, Coldwater, and Rice Lakes

\begin{tabular}{|c|c|c|c|c|c|}
\hline Depth (cm) & $\begin{array}{l}\text { Laboratory } \\
\text { number } \\
\text { (CAMS) }\end{array}$ & $\begin{array}{c}\text { Age } \\
\left({ }^{14} \mathrm{C} \text { yr B.P. }\right)\end{array}$ & $\begin{array}{l}\text { Error } \\
(1 \sigma)\end{array}$ & $\begin{array}{l}\text { Calibrated age } \\
\text { (cal yr B.P.)* } \\
(1 \sigma \text { range })\end{array}$ & Material \\
\hline \multicolumn{6}{|l|}{ Coldwater Lake } \\
\hline $773-777$ & 13612 & 620 & 60 & 596 (545-653) & \multirow{3}{*}{$\begin{array}{l}\text { Rumex and chenopod seeds, wood, charcoal } \\
\text { charcoal } \\
\text { chenopod seeds, wood, charcoal }\end{array}$} \\
\hline 1018-1022 & 17040 & 1610 & 60 & 1518 (1408-1546) & \\
\hline $1143-1147$ & 13613 & 2050 & 60 & 1989 (1930-2064) & \\
\hline $1430-1434$ & 6821 & 460 & 60 & $509(477-530)$ & \multirow{4}{*}{$\begin{array}{l}\text { charcoal } \\
\text { charcoal } \\
\text { charcoal } \\
\text { charcoal }\end{array}$} \\
\hline $1508-1512$ & 14337 & 830 & 60 & 725 (672-782) & \\
\hline $1562-1566$ & 14338 & 1080 & 50 & 966 (936-1055) & \\
\hline $1662-1667$ & 6822 & 2300 & 60 & 2334 (2206-2349) & \\
\hline \multicolumn{6}{|l|}{ Rice Lake } \\
\hline
\end{tabular}

* Calibrated dates are the mean of the interval of calendar dates with the highest probability of occurrence.

end moraine and is underlain by outwash that overlies the Pierre Shale (Cretaceous). Coldwater Lake lies on the Missouri Coteau in southeastern North Dakota, within the Burnstad drift, a late-Wisconsin morainal deposit of the James lobe of the Laurentide ice sheet. It is underlain by Pierre Shale (Clayton, 1962). Rice Lake is also on the Missouri Coteau, near the edge of the Missouri Escarpment in north-central North Dakota. The lake is within a meltwater channel underlain by outwash gravels and sands (Sloan, 1972).

\section{Methods}

\section{Sampling and Chronology}

Each of the lakes was cored during winter 1985-1986 with a modified Livingstone square-rod sampler (Wright, 1967). An 11.2-m sediment core, with a basal age of $11,800{ }^{14} \mathrm{C} \mathrm{yr}$ B.P., was collected from Moon Lake in $13.2 \mathrm{~m}$ of water. From Coldwater Lake an 18.8-m core was raised from $4.9 \mathrm{~m}$ of water; it has a basal age of $10,790{ }^{14} \mathrm{C}$ yr B.P. An $11.8-\mathrm{m}$ core taken in $8.6 \mathrm{~m}$ of water at Rice Lake has a basal age of 9,240 ${ }^{14} \mathrm{C}$ yr B.P. Details regarding chronology and the Holocene climate history of Coldwater and Moon lakes are described elsewhere (Laird et al., 1996a; Xia et al., 1997).

Core sections were stored at $4{ }^{\circ} \mathrm{C}$ prior to sampling. Dates are presented here in calendar years A.D., based on linear interpolation of the calibrated equivalent ages for each AMS date (Table 2) (Stuiver and Reimer, 1993), using the bidecadal calibration curve (Stuiver and Pearson, 1993). For Moon Lake, the uppermost $4 \mathrm{~m}$ of core, representing ca. 2,300 years, were sampled at $0.5-\mathrm{cm}$ intervals. The average sample resolution is 5.3 years. For Coldwater Lake, the top $6.1 \mathrm{~m}$ of sediment, representing 2,050 cal years, were sampled at 2-cm intervals. The final sampling resolution is approximately $8 \mathrm{cal}$ years, except for gaps created by prior sampling for AMS dating and century-scale analyses. For Rice Lake, the uppermost $5.5 \mathrm{~m}$ of sediment, representing 2,100 cal years, were sampled at ca. $1.5-\mathrm{cm}$ intervals, and the final sampling resolution averages about 14 cal years, except for gaps. Each sample interval was homogenized with a spatula prior to subsampling for various analyses.

At each site, a short core, encompassing the last ca. 200 years, was collected with a piston corer. Each short core was kept upright and extruded in the field at 1- to 4-cm intervals. Core chronology is based on ${ }^{210} \mathrm{~Pb}$ dating of the sediment using the constant rate of supply model (Appleby and Oldfield, 1978), verified by pollen analysis and the known dates for the introduction of exotic annuals, such as Salsola or cultivated crops (Jacobson and Engstrom, 1989). In Moon and Coldwater lakes, the uppermost sections of the long cores overlap with the base of the short cores, and the two core sequences have been integrated based on distinctive patterns in the losson-ignition (Coldwater) and diatom (Moon) stratigraphy.

\section{Diatoms}

Diatom analysis was completed for Moon and Coldwater lakes. Subsamples were processed in cold hydrogen peroxide (30\%) to oxidize organic matter and were rinsed with distilled water until free of peroxide. The resulting samples were settled onto coverslips and allowed to air-dry, and the coverslips were mounted onto slides with Naphrax ${ }^{\mathrm{TM}}$. Diatoms were counted in transects under oil immersion with a $100 \times$ objective. At most levels a minimum of 300 diatom valves was counted, but in a few samples diatom concentrations were low and/or preservation was poor, and fewer valves were counted.

Salinity reconstructions were based on a transfer function (Fritz et al., 1993) derived from a weighted-averaging regression and calibration model, which uses the diatom dis- 

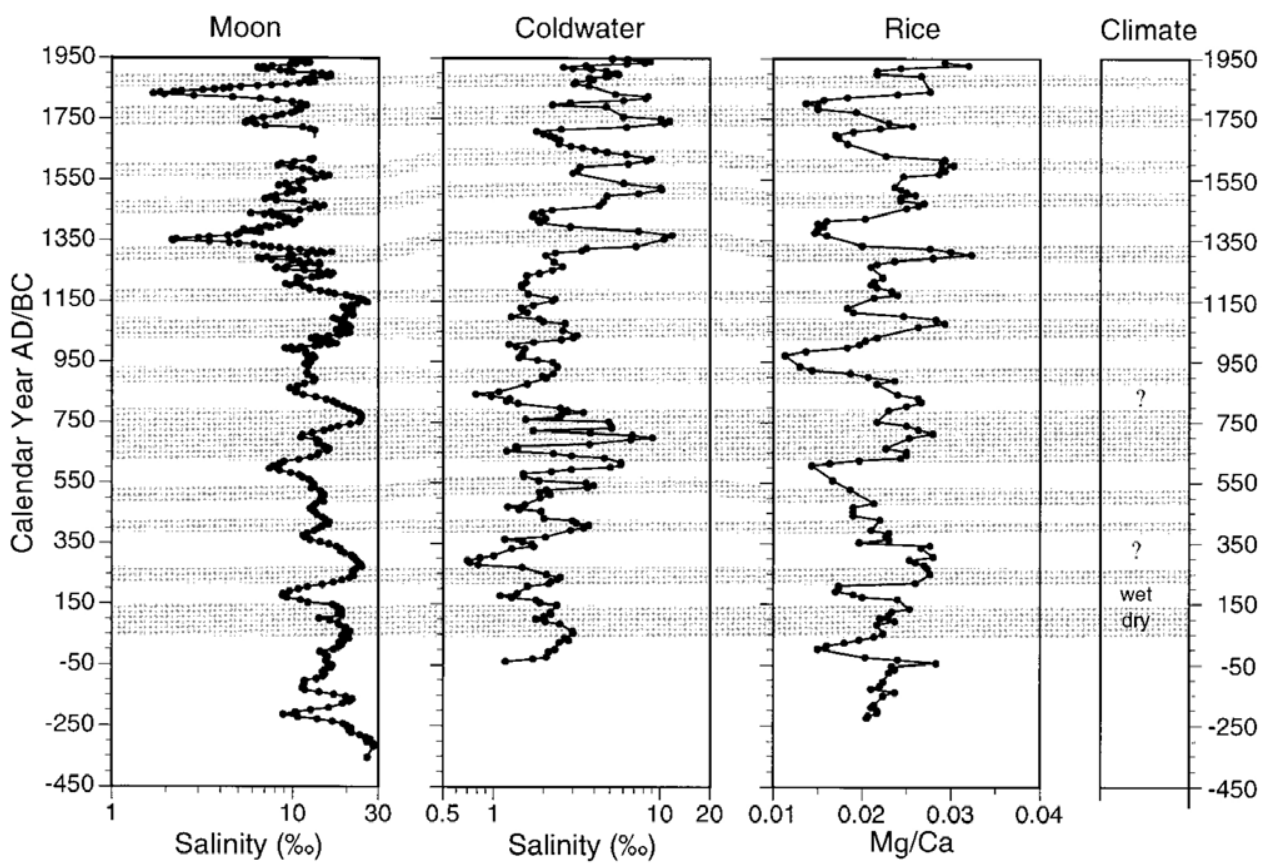

Figure 2. Diagram showing patterns of salinity change at the three lake sites in the northern Great Plains, arranged east (Moon) to west (Rice). Data from Coldwater and Rice lakes are smoothed with a 3-point running average and from Moon Lake with a 6-point running average. The gap in the Moon Lake record around A.D. 1600 is the result of desiccation of the core; thus, data are unavailable for this period. Shaded intervals represent times of major drought. Unshaded intervals indicate wetter periods, except for intervals where the three records differ, which are marked with question marks.

tribution in modern lakes in the northern Great Plains. Mean bootstrap estimates of salinity calculated from 1,000 cycles are highly correlated with the weighted-average salinity estimates $(r=0.99)$.

\section{Ostracode Trace-Element Chemistry}

Trace-element analysis was completed for Rice and Coldwater lakes. Concentrations of Candona were extremely low in the Moon Lake sediments, which precluded analysis of ostracode-shell chemistry at this site. The sediment subsamples (mostly 5-15 g) were soaked in Calgon solution and frozen/thawed before being washed through a set of sieves (150 and 250- $\mu \mathrm{m}$; Forester, 1987). Geochemical analyses were performed on juvenile shells (A-1 and A-2 instars) of Candona rawsoni (a benthic ostracode species with broad salinity tolerance), because juveniles are more restricted in the season of shell formation (Xia et al., 1997). Before the chemical analysis, the shells were cleaned with triply deionized distilled water and dried in residue-free ethanol.

Selected ostracode shells from Coldwater Lake were cleaned with $10 \% \mathrm{H}_{2} \mathrm{O}_{2}$ at $80^{\circ} \mathrm{C}$ for 20 min prior to analysis (Xia et al., 1997). Those from the Rice Lake core were not pretreated. A composite of 2-13 shells was used from each Rice Lake sample, and 8-20 valves were used for each Coldwater sample. Tandem trace-element/stable isotopic measurements were made from all ostracode samples (the isotopic data will be presented elsewhere). The trace-element analysis of ostracode shells was carried out on the acid residue (in
104\% ultrapure $\mathrm{H}_{3} \mathrm{PO}_{4}$ ) remaining after stable-isotope analysis (Chivas et al., 1993). The residue was diluted about 200 times with $0.5 \mathrm{M}$ high-purity distilled $\mathrm{HCl}$ for optimal measurement precision. The elemental ( $\mathrm{Ca}, \mathrm{Mg}$, Sr, and $\mathrm{Ba}$ ) concentration measurements of diluted residue samples were carried out on a Perkin- Elmer/Sciex Elan 5000 inductively coupled plasma mass spectrometer (ICP-MS). The analytical precision is within 5\% for concentration measurements of individual elements.

\section{Results}

\section{Moon Lake, Barnes County, ND}

The diatom stratigraphy and its interpretation have been presented in detail elsewhere (Laird et al., 1998; 1996b), and here we provide only a brief summary of these results. The 2,300-year record of diatom-inferred salinity shows oscillations between high- and low-salinity intervals (Figure 2), indicating shifts between dry and moist periods. Prior to A.D. 1200, the record shows long intervals of persistently high salinity $\left(.20 \mathrm{~g} \mathrm{~L}^{-1}\right)$, suggesting periods of multiple decades when droughts were severe and frequent. Most of this interval is typified by high salinity. Long periods of particularly high salinity are evident from A.D. 20-140, 220-340, 640820, and 1020-1160. Relative to the Dust Bowl era of the 20th century, when diatom-inferred salinity was $10-17 \mathrm{~g} \mathrm{~L}^{-1}$, the stratigraphic data suggest drought intervals more extreme 

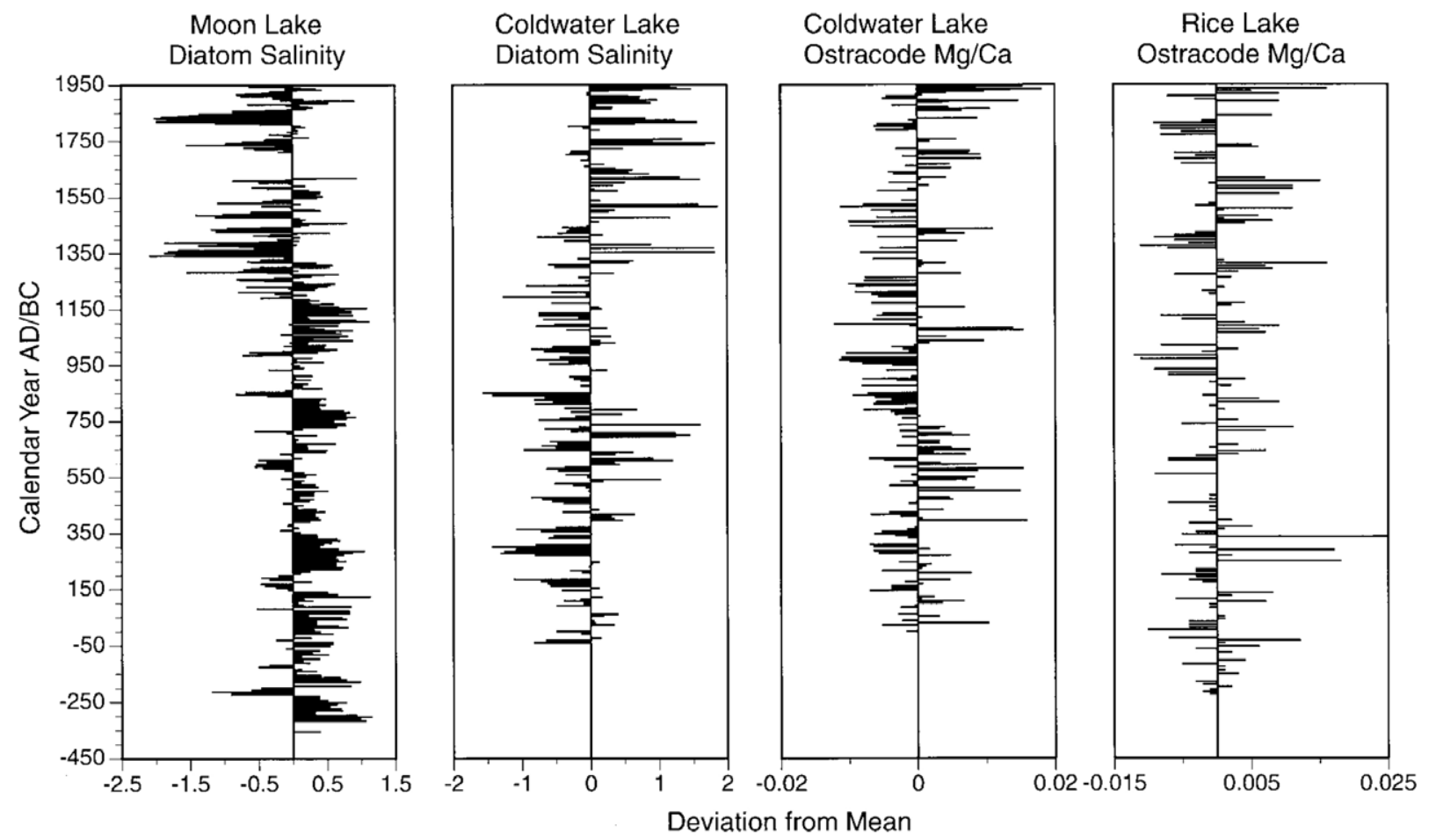

Figure 3. Deviation from the 2,000-year lake-water chemistry mean for the proxy records from Moon, Coldwater, and Rice lakes.

in magnitude and duration than those of the 20th century. The record shows that high salinity typifies the Medieval Period (A.D. 900-1300) (Hughes and Diaz, 1994); however, this period is not distinguished relative to the previous 1300 years.

The diatom-inferred salinity record indicates a major shift in mean salinity after A.D. 1200 (Figure 3), with several subsequent intervals being fresher than any within the previous 1,550 years of record. The shift to lower mean salinity suggests enhanced effective moisture beginning about 750 years ago, a time roughly coincident with the onset of the Little Ice Age (A.D. 1300- 1850; Porter, 1986). Two major freshwater extremes are evident about A.D. 1350 and 1850.

\section{Coldwater Lake, MacIntosh County, ND}

The diatom species record (Figure 4) shows oscillations between freshwater planktonic taxa (Fritz et al., 1993), such as Aulacoseira ambigua, Cyclotella michiganiana, Stephanodiscus niagarae, small Stephanodiscus species (S. minutulus, S. parvus, S. hantzschii), and Synedra acus with saline species, particularly Chaetoceros elmorei and Cyclotella quillensis. Both diatom-inferred salinity and $\mathrm{Mg} / \mathrm{Ca}$ ratios of the ostracode Candona rawsonii reflect changes in ionic concentration, and the two proxies show similar patterns in the direction and magnitude of change (Figure 5). The only discrepancies in direction of change are at A.D. 850-900, when diatom-inferred salinity increases whereas ostracode $\mathrm{Mg} / \mathrm{Ca}$ continues to decline, and around A.D. 1540, when diatom-inferred salinity shows a drop whereas ostracode $\mathrm{Mg} / \mathrm{Ca}$ remains high.
In a few intervals, the magnitude of inferred salinity change differs: around A.D. 200-300 and 700-800 the diatoms show larger fluctuations in salinity than the ostracodes, whereas the amplitude of salinity change between A.D. 1050 and 1300 is reduced in the diatom record relative to the ostracode record. Overall, however, the two proxy records are remarkably coherent.

The diatom and ostracode data show alternations between low- and high-salinity intervals during the last 2,000 years, each persisting for multiple decades. The data indicate that between A.D. 530 and 790, high-salinity periods were more common, suggesting a greater frequency of drought. This is followed by an interval of persistent low salinity between A.D. 800 and 1000, which suggests a long period of enhanced moisture availability. High salinity prevailed from A.D. 1020 to 1080 , followed by multiple oscillations between high and low salinity in the subsequent few centuries, although salinity was more frequently low relative to the long-term average (Figure 3). Salinity was generally higher during the last ca. 500 years, suggesting more frequent and persistent drought.

\section{Rice Lake, Ward County, ND}

The Mg/Ca data from Rice Lake (Figure 2) show periodic fluctuations at century scale around a 2,100-year mean value of 0.022 (Yu and Ito, 1999). The relatively dry periods include A.D. 40-150, 220-380, 630-930, 1020-1140, 13001350, 1500-1650, and the last century. The major wet periods are A.D. 400-620, 950-1020, 1350-1480, and 1650-1750. 


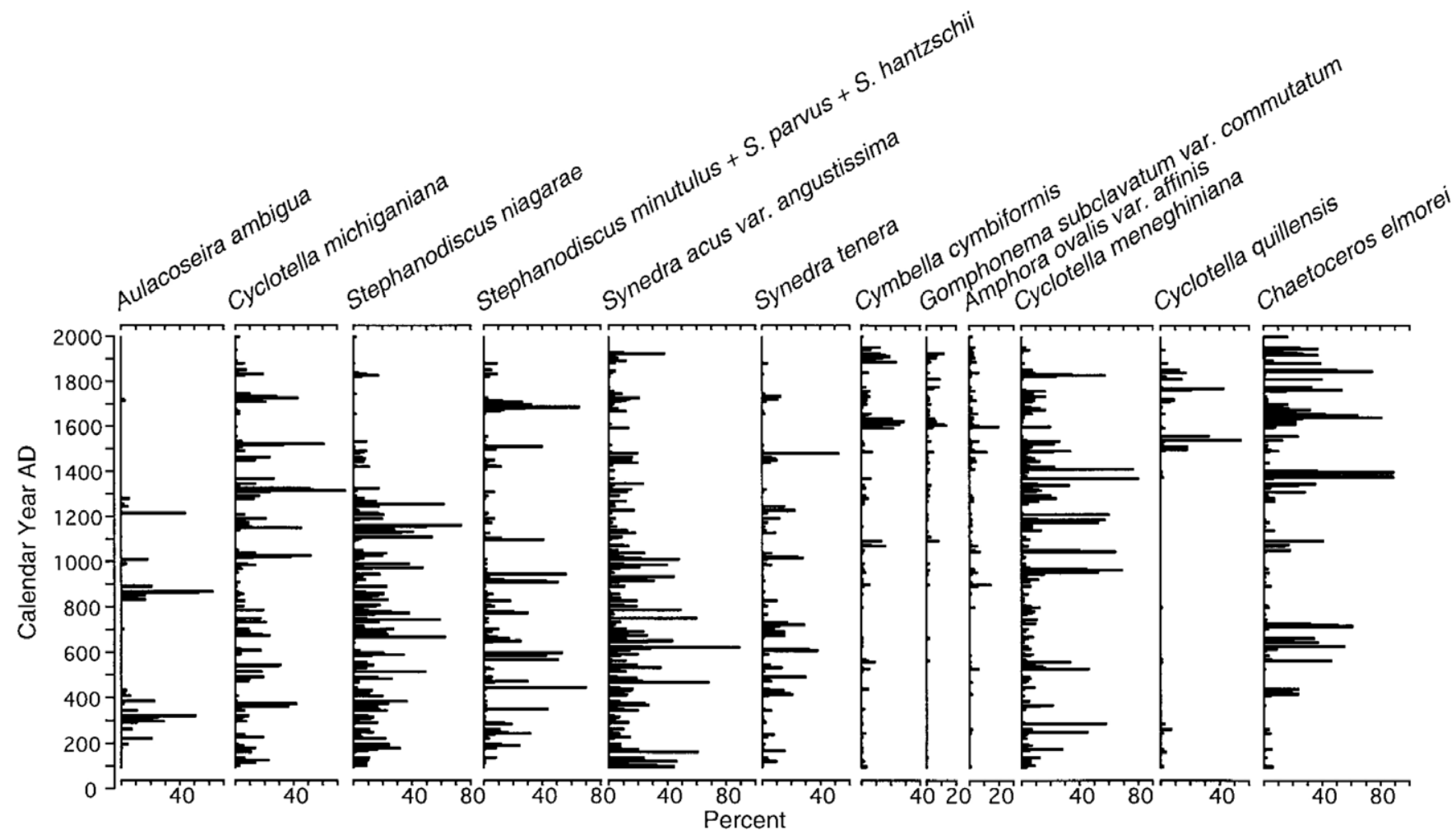

Figure 4. Summary diatom diagram of the major taxa used to infer salinity variations in Coldwater Lake.

The dry periods appear to last longer, although they incorporate lower-magnitude fluctuations, whereas the wet periods are short and more stable. These patterns suggest highly variable climate during the centuries of drought. The $\mathrm{Mg} / \mathrm{Ca}$ ratios from Rice Lake show no long-term trend over the last 2,100 years in lake-water salinity and thus aridity.

\section{Discussion}

\section{Comparison of Diatom and Ostracode Inferences}

Lake-water salinity and $\mathrm{Mg} / \mathrm{Ca}$ ratios are both measures of ion concentration. In lakes of the northern Great Plains, the two variables are highly correlated at salinities less than about $20 \mathrm{~g} \mathrm{~L}^{-1}$, indicating that $\mathrm{Mg} / \mathrm{Ca}$ behaves conservatively (Fritz et al., 1993; Ito et al., 1998; Last, 1992). Thus, both salinity and $\mathrm{Mg} / \mathrm{Ca}$ ratios should respond similarly to shifts in evaporative concentration or dilution, and proxy records of these two variables should change in tandem. A comparison of diatom-inferred salinity with ostracode-shell $\mathrm{Mg} / \mathrm{Ca}$ ratios for Coldwater Lake (Figure 5) shows very good agreement in the pattern of change in ionic concentration. Overall, the two records are also similar in the magnitude of salinity change, although there are discrepancies. For example, during several time intervals between A.D. 1050 and 1280, the magnitude of change in diatom-inferred salinity is lower than that inferred from ostracode shell chemistry. Given the good diatom preservation and the precision of measurement on multiple ostracode valves in this region of the core, we have no clear reason to favor one proxy over the other. Diatoms and ostracodes may live during different times of the year and thus may record differing water chemistries, but at present no data are available on potential seasonal biases of these biotic proxies. In such instances, the magnitude of salinity change can only be inferred by comparison with nearby sites (see below). Nevertheless, the overall coherency of the two proxy records indicates that each is a reliable indicator of salinity change in hyposaline (3-10 $\mathrm{g} \mathrm{L}^{-1}$ ) closed-basin lakes, such as Coldwater Lake.

\section{Regional versus Local Climate Patterns During the Last 2,000 Years}

Multisite comparisons from within a geographic region can be used to distinguish local from regional patterns of variation, although one cannot distinguish whether differences between sites are a result of local climatic variation or, alternatively, different hydrological responses to a similar climate forcing. The three lakes studied here are within a fairly uniform physiographic region, but they span a strong regional gradient in effective moisture and clearly do not have identical moisture budgets. Twentieth-century precipitation records for the climate stations closest to each of the lakes (Figure 6) show large-scale similarities in the pattern of variation; however, there are differences. All three sites show extremely low precipitation during the Dust Bowl period in the mid 1930s, 


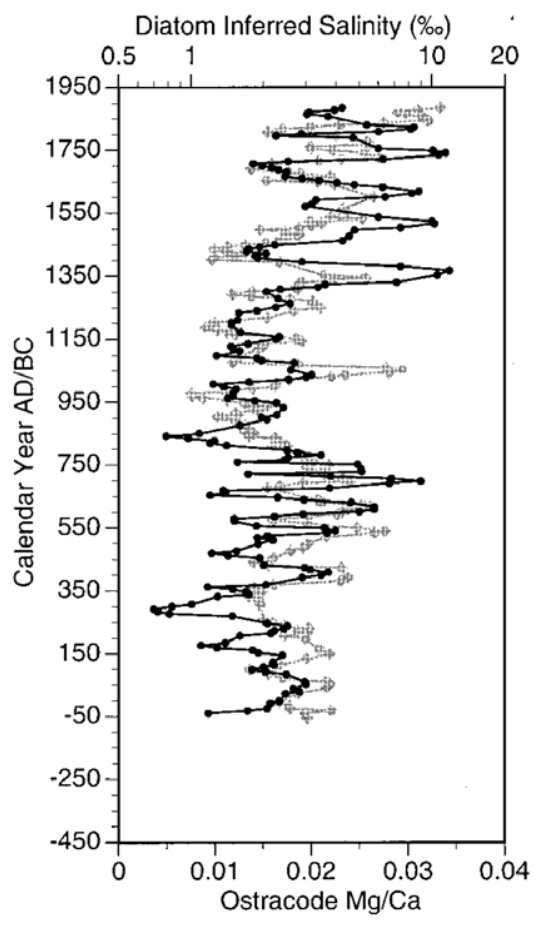

Figure 5. Comparison of Coldwater Lake diatom-inferred salinity (black) and ostracode $\mathrm{Mg} / \mathrm{Ca}$ (gray).

but the magnitude of the precipitation deficit is much greater at Ashley (near Coldwater Lake) than at Minot (Rice Lake) or Jamestown (Moon Lake). Similarly, the data show a gradual decline in precipitation from the early 1920s to mid-1930s at both Minot and Jamestown, but a more rapid decline at Ashley. A drought centered around 1960 was less pronounced at the eastern sites than at Minot, where precipitation was nearly as low as that in the 1930s. At the westernmost station in Minot, a directional shift to generally higher precipitation and enhanced precipitation variation is seen after the 1930s, but the opposite is true at the more easterly sites. Given these differences in the modern climate, there is every reason to expect variation in paleoclimatic reconstructions, even at this small geographic scale, particularly with respect to magnitude of change.

The reconstructions from Moon, Coldwater, and Rice lakes all indicate that the climate of the last 2,000 years was hydrologically complex, with large oscillations between low-salinity wet phases and high-salinity dry phases. The three sites show a moderate degree of coherence in pattern of change. However, it is difficult to reconcile the fine-scale behavior of the lakes, partly because of the errors inherent in the chronology. The high sediment-accumulation rates in prairie lakes (commonly $.0 .25 \mathrm{~cm} \mathrm{yr}^{-1}$ ) permit high-resolution sampling, but the chronology is derived from radiocarbon dates (Table 2 ), each of which has an associated standard error of at least 650 years. In Figure 2 we have used shading to connect intervals that are apparently synchronous and to emphasize the broad-scale similarities in direction of change. Quite clearly, a slight shift in the time scale at various points could improve the intercorrelation of salinity trends or, alternatively, result in inverse behavior. Thus, we present the suggested correlation as a working hypothesis of regional patterns.

The three lakes show considerable similarity in direction of change, although there are intervals of apparent divergence. All records show an interval of prolonged drought between ca. A.D. 40 and 130, followed by a wetter period, and also a dry period about A.D. 250, which two of the records (Moon and Rice) suggest was sustained for more than a century. Shorter periods of drought are evident at ca. A.D. 400 and 530, and the data suggest a period of major and sustained drought from ca. A.D. 620 to 790. The time from A.D. 1020 to 1150 was also characterized by major drought and was followed by a distinct wet interval to at least A.D. 1300. In the few centuries after A.D. 1300, the Moon Lake stratigraphy is somewhat offset from the other two sites, but the correlation suggested in Figure 2 is well within the error of the radiocarbon dates. All sites show intervals of very fresh conditions, suggesting high precipitation, sometime between A.D. 1330 and 1430 and in

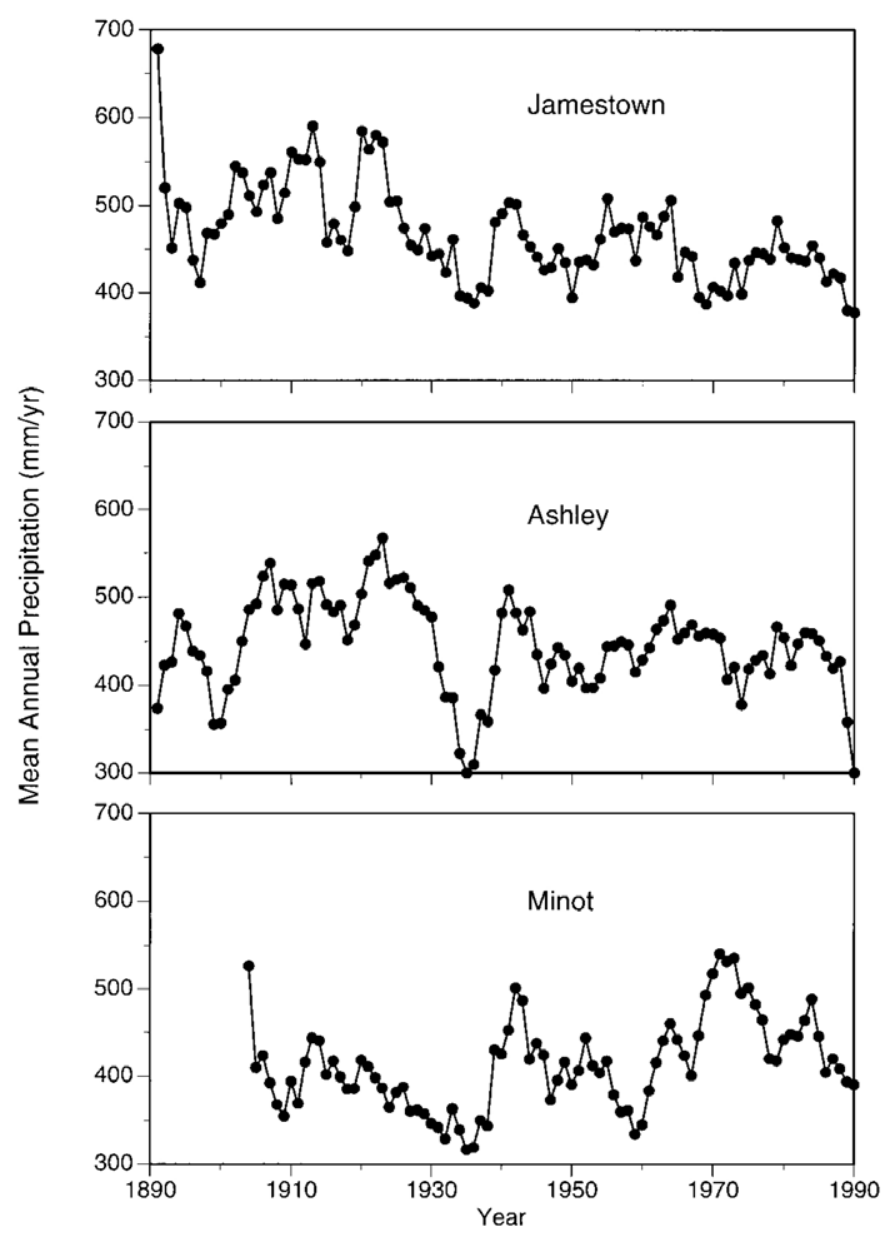

Figure 6. Mean annual precipitation $\left(\mathrm{mm} \mathrm{yr}^{-1}\right)$ in the 20th century for the three climate stations closest to the three North Dakota lake sites discussed in the text. Data are smoothed with a 5-point running average. 
the early decades of the 1800s. The data also suggest periods of drought in the decades surrounding A.D. 1500, 1600, and 1800 , and in the latter decades of the 19th century.

Neither the Medieval Period nor the Little Ice Age interval can be simply characterized in the northern Great Plains with respect to moisture conditions, and both wet and dry conditions alternated within each. Climatic extremes were typical of some regions during the Medieval Period (Barlow et al., 1997; Stine 1994), and our evidence suggests multidecadal intervals of major drought in the northern Great Plains. However, our data suggest that moisture deficits during Medieval times are not unusual relative to the previous 1,000 years of record, and the magnitude of Medieval drought in the northern Great Plains is apparently not as extreme as that of the middle Holocene (Dean et al., 1996; Laird et al., 1996a; Smith et al., 1997; Xia et al., 1997).

One of the most striking differences among the records occurs after A.D. 1200. Both Coldwater and Rice lakes show multidecadal periods of very high salinity (Figure 2), which suggest intervals of drought as extreme as any within the 2,000-year record. In fact, the Coldwater Lake record suggests a trend toward generally higher salinity (Figure 3). However, after A.D. 1200, the Moon Lake stratigraphy shows a shift to lowered mean salinity (Figure 3). This shift in lake-water chemistry at Moon Lake was originally interpreted as an overall increase in moisture during the Little Ice Age (Laird et al., 1996b). This interpretation is consistent with pollen records several hundred kilometers to the east of Moon Lake, which show the expansion of mesic tree species at the onset of the Little Ice Age in forested regions of eastern Minnesota (Grimm, 1983). However, the absence of a directional shift toward fresher conditions at Rice and Coldwater lakes casts doubt upon the interpretation of an overall regional increase in moisture during the last 600-700 years.

Very few other paleoclimatic records from the northern Great Plains are sufficiently detailed or of sufficient duration to evaluate the character of the Little Ice Age interval relative to the previous millennium (Woodhouse and Overpeck, 1998). A record of eolian activity inferred from sedimentary A1 concentrations from Elk Lake, MN (Dean, 1997) shows low flux during some of the Little Ice Age interval. However, there is no directional pattern of change relative to earlier times, and a period of high aluminum flux in the 17th century suggests an interval of extreme drought equivalent in magnitude to two intervals of inferred drought in Medieval times. A highresolution oxygen isotope record from Lake Mina, MN, less than $100 \mathrm{~km}$ from Elk Lake, spans only 1,200 years, but it shows generally higher values after A.D. 1300 relative to the preceding 500 years, and the higher values suggest enhanced evaporative forcing (Stevens, 1997). Records of eolian activity both near Minot (Muhs et al., 1997) and to the south in the Nebraska Sandhills (Stokes and Swinehart, 1997) indicate dune reactivation at several times during the last millennium in response to major drought, including at least two intervals during the last 500 years. Thus, there is no widespread evidence indicating a general increase in moisture availability in the northern Great Plains during the last 600-700 years. Additional sites are necessary to address this hypothesis adequately.

\section{Causes of Spatial Variability among Lake Records}

The differences in behavior among Moon, Coldwater, and Rice lakes suggest either differences in local climate or differences in hydrologic response to environmental variability. Within the last century, droughts have been spatially heterogeneous, even within a fairly small geographic area, and widespread droughts, such as the Dust Bowl droughts, have been infrequent (Oladipo, 1986). Thus, it is possible that Moon Lake had a generally moister climate after A.D. 1200, while nearby sites just to the west did not. However, it seems unlikely that such a strong climatic gradient would occur between two closely spaced sites (Moon and Coldwater are $<200 \mathrm{~km}$ from one another) and would persist for many centuries.

A more likely explanation for the differences between the sites is shifts in the hydrologic behavior of individual lake systems as a result of altered ground-water flow patterns (Smith et al., 1997) or within-lake mixing processes (Fee et al., 1995). Several recent studies have demonstrated differential sensitivity of lakes to drought based on topographic position within a drainage basin (Almendinger, 1993; Webster et al., 1996) or the permeability of surface deposits. All three lakes in this study were chosen because of their small catchments and relative hydrologic simplicity; nevertheless, there are several differences in overall hydrology that have the potential to produce differential responses to climate shifts. Coldwater and Rice lakes lie at higher elevation (Table 2) on the Missouri Coteau, whereas Moon Lake lies just to the east of the Coteau. Drainage patterns associated with the elevation differences may affect groundwater flow pattern. Both Moon and Rice lakes lie within meltwater channels and thus are hydrologically connected via groundwater flow to other basins within this local flow field. By contrast, Coldwater Lake is in till, which is less permeable and potentially less sensitive to groundwater flow. Moon Lake is relatively simple morphometrically, whereas both Rice and Coldwater lakes have adjacent wetlands or shallow basins that would be connected to the main lake during times of high water level. Thus, during high-water stages, lake surface area is greatly increased, which in turn would amplify the evaporative response of the lake (Mason et al., 1994). One can speculate that the directional shift of Moon Lake to lowered mean salinity, for example, may have resulted from a change in the configuration of the local groundwater system, which increased fresh groundwater flow into the lake or, alternatively, increased solute losses from the lake so that the lake fluctuated around an altered mean baseline. At Coldwater Lake, both the diatom and ostracode inferences suggest generally higher salinity over the last 500 years, and 
this could reflect a high lake level accompanied by an increase in the relative contribution of evaporative forcing due to vastly increased surface area/volume ratio. The salinity response of Moon Lake may be very sensitive to spring recharge, whereas Coldwater and Rice lakes may be more strongly driven by summer evaporative forcing. Changes in lake morphometry and mixing behavior as a result of gradual infilling can also alter hydrologic response. Moon Lake, for example, has a relatively small deep hole and may have been prone to meromixis as a result of its morphometry and higher salinity (Laird et al., 1996a). Without more detailed characterization and modeling of the groundwater and hydrologic setting of these individual lake basins, we can only speculate regarding the influence of these hydrologic differences on lake behavior.

\section{Late-Holocene Climate Variation and Its Causes}

Despite the differences in long-term salinity trends exhibited by these lakes, there is a good agreement regarding direction of salinity change and inferred climate fluctuations. From the vantage point of the 20th century, these three North Dakota sites suggest that droughts equal or greater in magnitude to those of the Dust Bowl period were a common occurrence during the last 2,000 years and that severe droughts may have been frequent for multiple decades within this period. Thus, the duration of major drought may have been greater at times during the 2,000 years, such that high-salinity intervals were more persistent than in the 20th century, a pattern evident in other records from the western United States (Woodhouse and Overpeck, 1998). This postulated change in the duration of dry periods implies shifts in the persistence and strength of the atmospheric circulation patterns associated with drought (Higgins et al., 1997; Namias, 1983; Trenberth et al., 1988) on multidecadal time scales. Recent studies from the northern Great Plains and western North America (Cook et al., 1997; Dean, 1997; Laird et al., 1996b; Yu and Ito, 1999) have shown a correlation between solar forcing and centennial- and decadal-scale drought patterns. Thus, solar variability may influence the duration of dry periods through its impact on convective activity and circulation (Rind and Overpeck, 1993).

\section{Acknowledgments}

Eric Grimm obtained the cores and provided some of the AMS radiocarbon dates. P. Mueller, B. Haskell, J. Xia, R. McEwan, and R. Knurr assisted with core sampling and laboratory analyses. We thank B. Cumming for statistical advice and E. Grimm, J. Almendinger, J. Donovan, and A. Smith for helpful discussions on regional paleohydrology. This research was funded by the NSF (ATM 94-14381 and ATM 96-32040) and NOAA (NA36GPO302) and is a contribution by PRAIRIE (Paleoecological Reconstructions of Aridity: Interdisciplinary Research Iniative).

\section{References}

Almendinger, J. E., A groundwater model to explain past lake levels at Parkers Prairie, Minnesota, USA. The Holocene 3 (1993), pp. 105-115.

Appleby, P. G., and F. Oldfield, The calculation of lead-210 dates assuming a constant rate of supply of the unsupported lead-210 to the sediment. Catena 5 (1978), pp. 1-8.

Barlow, L. K., J. P. Sadler, A. E. J. Ogilvie, P. C. Buckland, T. Amorosi, J. H. Ingimundarson, P. Skidmore, A. J. Dugmore, and T. H. McGovern, Interdisciplinary investigations of the end of the Norse western settlement in Greenland. The Holocene 7 (1997), pp. 489-500.

Bryson, R. A., Air masses, streamlines, and the boreal forest. Geographical Bulletin 8 (1966), pp. 228-269.

Carpenter, J. R., The grassland biome. Ecological Monographs 10 (1940), pp. 618-684.

Chivas, A. R., P. DeDeckker, J. A. Cali, A. Chapman, E. Kiss, and J. M. G. Shelly, Coupled stable-isotope and trace-element measurements of lacustrine carbonates as paleoclimatic indicators. In: P. K. Swart, K. C. Lohmann, J. McKenzie and S. Savin, Editors, Climate Change in Continental Isotopic Records, American Geophysical Union, Washington (1993), pp. 113-121.

Clayton, L., Glacial geology of Logan and McIntosh Counties, North Dakota. North Dakota Geological Survey Bulletin 37 (1962), pp. 1-84.

Cook, E. R., D. M. Meko, and C. W. Stockton, A new assessment of possible solar and lunar forcing of the bidecadal drought rhythm in the western United States. Journal of Climate 10 (1997), pp. 1343-1356.

Crowe, A. S., The application of a coupled water-balance-salinity model to evaluate the sensitivity of a lake dominated by groundwater to climate variability. Journal of Hydrology 141 (1993), pp. 33-73.

Dean, W. E., Rates, timing, and cyclicity of Holocene eolian activity in north-central United States: Evidence from varved lake sediments. Geology 25 (1997), pp. 331-334.

Dean, W. E., T. S. Ahlbrandt, R. Y. Anderson, and J. P. Bradbury, Regional aridity in North America during the middle Holocene. The Holocene 6 (1996), pp. 145-155.

Donovan, J. J., Measurement of reactive mass fluxes in evaporative groundwater-source lakes. In: R. Renaut and W. M. Last, Editors, Sedimentology and Geochemistry of Modern and Ancient Saline Lakes, SEPM Society for Sedimentology Geology (1994), pp. 33-50.

Fee, E. J., R. E. Hecky, S. E. M. Kasian, and D. R. Cruikshank, Effects of lake size, water clarity, and climatic variability on mixing depths in Canadian Shield lakes. Limnology and Oceanography 41 (1995), pp. 912-920.

Forester, R. M., Late Quaternary paleoclimate records from lacustrine ostracodes. In: W. F. Ruddiman and H. E. Wright, Jr., Editors, North America and Adjacent Oceans during the Last Deglaciation, The Geology of North America, Geological Society of America, Boulder (1987), pp. 261-276.

Fritz, S. C., S. Juggins, and R. W. Battarbee, Diatom assemblages and ionic characterization of lakes of the Northern Great Plains, North America: A tool for reconstructing past salinity and cli- 
mate fluctuations. Canadian Journal of Fisheries and Aquatic Sciences 50 (1993), pp. 1844-1856.

Grimm, E. C., Chronology and dynamics of vegetation change in the prairie-woodland region of southern Minnesota, U.S.A. New Phytologist 93 (1983), pp. 311-350.

Higgins, W. R., Y. Yao, E. S. Yarosh, J. E. Janowiak, and K. C. Mo, Influence of the Great Plains low-level jet on summertime precipitation and moisture over the central United States. American Meteorological Society, Bulletin 10 (1997), pp. 481-507.

Hirschboeck, K. K.1991. Climate and floods. USGS Water Supply Paper 2376, pp. 67-88.

Hughes, M., and H. F. Diaz, Was there a Medieval Warm Period, and if so, where and when. Climatic Change 26 (1994), pp. 109-142.

Ito, E., Z. Yu, D. R. Engstrom, and S. C. Fritz, Is paleoclimatic interpretation of oxygen isotope records from glaciated Great Plains possible. Abstracts, AMQUA 15 (1998), p. 119.

Jacobson, H. A., and D. R. Engstrom, Resolving the chronology of recent lake sediments: An example from Devils Lake, North Dakota. Journal of Paleolimnology 2 (1989), pp. 81-98.

Kelly, T. E., and D. A. Block, Geology and ground water resources, Barnes County, North Dakota. Part I: Geology. North Dakota Geological Survey Bulletin 43 (1967).

Kelly, T. E., Geology and ground water resources, Barnes County, North Dakota. Part III: Ground water resources. North Dakota Geological Survey Bulletin 43 (1966).

Laird, K. R., S. C. Fritz, and B. F. Cumming, A diatom-based reconstruction of drought intensity, duration, and frequency from Moon Lake, North Dakota: A sub-decadal record of the last 2300 years. Journal of Paleolimnology 19 (1998), pp. 161-179.

Laird, K. R., S. C. Fritz, E. C. Grimm, and P. G. Mueller, Centuryscale paleoclimatic reconstruction from Moon Lake, a closed-basin lake in the northern Great Plains. Limnology and Oceanography 41 (1996a), pp. 890-902.

Laird, K. R., S. C. Fritz, K. A. Maasch, and B. F. Cumming, Greater drought intensity and frequency before AD 1200 in the Northern Great Plains, USA. Nature 384 (1996b), pp. 552-555.

Last, W. M., Chemical composition of saline and subsaline lakes of the northern Great Plains, western Canada. International Journal of Salt Lake Research 1 (1992), pp. 47-76.

Mann, M. E., R. S. Bradley, and M. K. Hughes, Global-scale temperature patterns and climate forcing over the past six centuries. $\mathrm{Na}$ ture 392 (1998), pp. 779-787.

Mason, I. M., M. A. J. Guzkowska, and C. G. Rapley, The response of lake levels and areas to climatic change. Climatic Change $\mathbf{2 7}$ (1994), pp. 161-197.

Meko, D. M., Dendroclimatic evidence from the Great Plains of the United States. In: R. S. Bradley and P. D. Jones, Editors, Climate Since A.D. 1500, Routledge, New York (1992), pp. 312-330.

Muhs, D. R., T. W. J. Stafford, J. Been, S. Mahan, J. Burdett, G. Skipp, and Z. Muhs Rowland, Holocene eolian activity in the Minot Dune Field, North Dakota. Canadian Journal of Earth Sciences 34 (1997), pp. 1442-1459.

Namias, J., Some causes of United States droughts. Journal of Climate and Applied Meteorology 22 (1983), pp. 30-39.

Oladipo, E. O., Spatial patterns of drought in the interior plains of North America. Journal of Climate 6 (1986), pp. 495-513.
Overpeck, J. P., K. Hugen, D. Hardy, R. Bradley, R. Case, M. Douglas, B. Finney, K. Gajewski, G. Jacoby, A. Jennings, S. Lamoureux, A. Lasca, G. MacDonald, J. Moore, M. Retelle, S. Smith, A. Wolfe, and G. Zielinski, Arctic environmental change of the last four centuries. Science 278 (1997), pp. 1251-1256.

Porter, S. C., Pattern and forcing of Northern Hemisphere glacier variations during the last millennium. Quaternary Research 26 (1986), pp. 27-48.

Rind, D., and J. Overpeck, Hypothesized causes of decade to century scale climate variability: Climate model results. Quaternary Science Reviews 12 (1993), pp. 357-374.

Sloan, C. E.1972. Ground-water hydrology of prairie potholes in North Dakota. U.S. Geological Survey Professional Paper, 585C, pp. 1-28.

Smith, A. J., J. J. Donovan, E. Ito, and D. R. Engstrom, Ground-water processes controlling a prairie lake's response to middle Holocene drought. Geology 25 (1997), pp. 391-394.

Stevens, L. R.. The Stable Isotopic Composition of Varved Lake Sediment: Implications for Climatic Change in Minnesota, University of Minnesota (1997).

Stine, S., Extreme and persistent drought in California and Patagonia during mediaeval time. Nature 369 (1994), pp. 546-549.

Stokes, S., and J. B. Swinehart, Middle- and late-Holocene dune reactivation in the Nebraska Sand Hills, USA. The Holocene 7 (1997), pp. 263-272.

Stuiver, M., and G. W. Pearson, High-precision bidecadal calibration of the radiocarbon timescale, AD 1950-500 BC and 2500-6000 BC. Radiocarbon 35 (1993), pp. 1-23.

Stuiver, M., and P. J. Reimer, Extended ${ }^{14} \mathrm{C}$ data base and revised CALIB 3.0 14C age calibration program. Radiocarbon 35 (1993), pp. 215-230.

Trenberth, K. E., G. W. Branstator, and P. A. Arkin, Origins of the 1988 North American drought. Science 242 (1988), pp. 1640-1645.

Webster, K. E., T. K. Kratz, C. J. Bowser and J. J. Magnuson, The influence of landscape position on lake chemical responses to drought in northern Wisconsin. Limnology and Oceanography 41 (1996), pp. 977-984.

Winter, T. C., and M. Woo, Hydrology of lakes and wetlands. In: M. G. Wolman and H. C. Riggs, Editors, Surface Water Hydrology, Geological Society of America, Boulder (1990), pp. 159-188.

Woodhouse, C. A., and J. T. Overpeck, 2000 years of drought variability in the central United States. American Meteorological Society, Bulletin 79 (1998), pp. 2693-2714.

Wright, H. E., A square-rod piston sampler for lake sediments. Journal of Sedimentary Petrology 37 (1967), pp. 975-976.

Xia, J., D. R. Engstrom, and E. Ito, Geochemistry of ostracode calcite: Part 2. The effects of water chemistry and seasonal temperature variation on Candona rawsoni. Geochimica et Cosmochimica Acta 61 (1997), pp. 383-391.

Xia, J. J., B. J. Haskell, D. R. Engstrom, and E. Ito, Holocene climate reconstructions from tandem trace-element and stable-isotope composition of ostracodes from Coldwater Lake, North Dakota, USA. Journal of Paleolimnology 17 (1997), pp. 85-100.

Yu, Z. C., and E. Ito, Possible solar forcing of century-scale drought frequency in the northern Great Plains. Geology 27 (1999), pp. 263-266. 